Number 4

\title{
UJI ANGKA KAPANG KHAMIR DAN IDENTIFIKASI Aspergillus species PADA JAMU KUNYIT DI DENPASAR SELATAN
}

\author{
Kadek Dewi Amba Rahayu', I Nyoman Jirna ${ }^{2}$, Burhannuddin ${ }^{3}$ \\ 1,2,3 Poltekkes Denpasar \\ nyomanjirna@ymail.com
}

\begin{abstract}
:
Background: Jamu kunyit is one of the traditional medicine that is believed to cure some diseases and very popular by the community. Jamu kunyit can be reduced in quality if there were mold, yeast, and the presence of Aspergillus sp.

Purpose: This study is to determine the number of mold yeast, and identify Aspergillus sp. on jamu kunyit that sold in Denpasar Selatan.

Methode: This study was descriptive by using cluster sampling technique. Jamu kunyit were cultured on SDA media, and the growing colonies were calculated to determine the value of the number mold and yeast. From the number a mold and yeast examination, there were 8 samples of jamu kunyit that exceeded standard (35\%) and 15 samples of jamu kunyit in normal range (65\%), 2 samples of jamu kunyit showed positive Aspergillus sp. and 21 samples of jamu kunyit negative Aspergillus sp. the type of Aspergillus found is Aspergillus niger.

Result: Many factors that can cause mold and yeast contamination are packaging, production, and storage.
\end{abstract}

Keyword : Jamu kunyit, the number of mold yeast, Aspergillus sp.

\section{PENDAHULUAN}

Denpasar Selatan merupakan salah satu kecamatan yang ada di kota Denpasar. Kecamatan ini terdiri atasenam kelurahan dan empat desa antara lain Kelurahan Renon, Kelurahan Sesetan, Kelurahan Pedungan, Kelurahan Sanur, Kelurahan Panjer, Kelurahan Serangan, Desa Sanur Kaja, Desa Sanur Kauh, Desa Sidakarya dan Desa Pamogan. Pada penelitian ini dipilih Denpasar Selatan karena kecamatan Denpasar Selatan memiliki jumlah penduduk yang cukup padat mencapai 279.640 jiwa $^{1}$

Dari data tersebut dapat dilihat bahwa penduduk di Denpasar Selatan cukup banyak sehingga banyak pula ditemukan pedagang jamu di Denpasar Selatan dan banyak masyarakat Denpasar Selatan yang masih mengkonsumsi jamu. Pedagang jamu di Denpasar Selatan dapat ditemukan di pinggir jalan maupun pedagang jamu gendong yang berkeliling. Berdasarkan survey yang telah dilakukan oleh peneliti bahwa di kelurahan Renon terdapat pedagang jamu sebanyak 8 pedagang, kelurahan Sesetan terdapat pedagang jamu sebanyak 7 pedagang, kelurahan Pedungan terdapat pedagang jamu sebanyak 6 pedagang, kelurahan Sanur tidak ditemukan pedagang jamu, kelurahan Panjer ditemukan pedagang jamu sebanyak 4 pedagang, kelurahan Serangan tidak ditemukan pedagang jamu, desa Sanur

Meditory | ISSN Online : 2549-1520, ISSN Cetak : 2338 - 1159, Vol. 7, No. 1, Juni 2019

HIm. 17 - 26, http://ejournal.poltekkes-denpasar.ac.id/index.php/M 
Kaja ditemukan 1 pedagang jamu, desa

Sanur Kauh ditemukan 1 pedagang jamu, desa Sidakarya ditemukan pedagang jamu sebanyak 7 pedagang dan desa Pamogan ditemukan pedagang jamu sebanyak 8pedagang. Terdapat berbagai macam jamu yang dijual di Denpasar Selatan salah satunya adalah jamu kunyit.

Jamu kunyit sangat digemari karena memiliki segudang khasiat, seperti dapat memancarkan aura kecantikan, dapat digunakan sebagai obat keputihan, pereda nyeri haid, menghilangkan demam, diare, dispepsia (perut kembung, nyeri, mual, tidak nafsu makan), eksim dan borok, gatal akibat cacar air, radang amandel, radang rahim, radang usus buntu, hepatitis, radang gusi, tekanan darah tinggi, dan terlambat haid, memperlancar ASI, dan mengatasi amandel $^{2}$.

Jamu yang dikonsumsi dapat berubah mutunya apabila terdapat beberapa faktor luar seperti cahaya matahari, oksigen, penyerapan air, adanya serangga, dan jamur. Dengan adanya faktor yang dapat menurunkan mutu jamu maka penting untuk mengetahui faktor yang membantu melindungi kestabilan mutu jamu, seperti lama penyimpanan dan tempat penyimpanan jamu yang benar sehingga mutu jaminan dapat tercapai optimal.
Dalam penyimpanan obat tradisional dipersyaratkan agar disimpan pada suhu ruang yaitu pada suhu $25^{\circ} \mathrm{C}$ sampai $30^{\circ} \mathrm{C}$, disimpan ditempat kering (terhindar dari kelembaban) dan terlindung dari sinar matahari ${ }^{3}$.

Penentuan kualitas jamu dapat dilakukan dengan parameter mikrobiologi salah satunya yaitu menguji Angka Kapang Khamir,yang menunjukkan adanya cemaran kapang khamir dalam sediaan. Pengujian AKK dilakukan untuk menjamin bahwa sediaan tidak mengandung jamur dari batas yang telah ditetapkan karena keberadaan jamur pada sediaan dapat mempengaruhi stabilitas sediaan tersebut dan dapat menurunkan mutu jamu. Menurut BPOM RI No. 12 tahun 2014 tentang persyaratan obat tradisional bahwa cairan obat yang akan dikonsumsi tidak boleh mengandung Angka Kapang Khamir lebih dari $10^{3}$ koloni/mL. Jika ditemukan AKK dalam sampel jamu yang diuji melebihi ambang batas yang telah ditentukan, maka sampel jamu tersebut tidak layak dikonsumsi karena berbahaya bagi kesehatan konsumen. Kondisi tersebut memungkinkan adanya pertumbuhan jenis kapang tertentu seperti jamur Apergillus species ( $s p$ ). Aflatoksin yang diproduksi oleh Apergillus sp. bersifat toksik karena 
dapat menyebabkan terjadinya sirosis dan karsinoma hati. Jumlah kapang dan khamir yang besar, dan terdapat adanya jamur Aspergillus sp. menunjukkan kemunduran dari mutu obat tradisional ${ }^{4}$.

Berdasarkan survey pendahuluan yang penulis lakukan, penjual jamu kunyit di kawasan Denpasar Selatan kurang higienis dilihat dari penggunaan botol penyimpanan jamu yang digunakan secara terus menerus sehingga pada mulut botol penyimpanan jamu masih menempel sisa-sisa jamu sebelumnya sehingga timbul kecurigaan tumbuhnya jamur pada botol penyimpanan jamu tersebut. Pada saat jamu dipanaskan dan dipindahkan kedalam botol jamu dan kemudian ditutup rapat akan menimbulkan adanya uap air yang dapat menjadi tempat tumbuhnya jamur pada botol jamu. Jamu kunyit yang beredar di Denpasar Selatan apabila tidak laku terjual maka jamu kunyit tersebut akan disimpan dalam waktu yang tidak ditentukan, sehingga timbul kecurigaan tumbuhnya jamur pada jamu tersebut mengingat bahwa jamur dapat tumbuh dengan cepat pada media yang lembab. Banyak ditemukan jamu kunyit yang tidak mencantumkan nomor registrasi BPOM dan tanggal kadaluarsa sehingga tidak diketahui secara pasti jamu kunyit tersebut layak untuk dikonsumsi atau tidak.

Penelitian yang dilakukan tentang uji AKK terhadap dua pedagang yaitu dari pedagang satu diperoleh nilai AKK

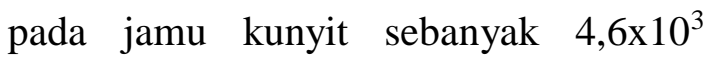
koloni/mL, dan dari pedagang dua diperoleh nilai AKK pada jamu kunyit sebanyak $9,6 \times 10^{2} \quad$ koloni $/ \mathrm{mL}$ yang menunjukkan bahwa jamu tersebut tidak layak dikonsumsi karena jumlah Angka Kapang Khamirnya melebihi batas yang telah ditentukan ${ }^{5}$. Penelitian tentang identifikasi kapang pada empat sampel jamu yaitu jamu beras kencur, kunyit, sirih dan sambiloto, jenis kapang yang paling banyak ditemukan dari keempat sampel jamu tersebut adalah Aspergillus niger dan Aspergillus flavus ${ }^{6}$.

Berdasarkan observasi yang telah penulis lakukan, bahwa banyak jamu kunyit di Denpasar Selatan beredar secara bebas tanpa adanya ijin edar dan tidak melalui proses uji keamanan dan kualitas obat tradisional karena tidak mencantumkan nomor registrasi BPOM dan tanggal kadaluarsa, sehingga tidak dapat diketahui sediaan tersebut layak untuk dikonsumsi atau tidak. Maka, penulis tertarik untuk mengetahui kualitas jamu kunyit yang dijual di kawasan Denpasar Selatan dengan menggunakan parameter mikrobiologi 
yaitu AKK dan identifikasi Aspergillus $s p$.

\section{METODE}

Penelitian ini menggunakan penelitian deskriptif. Pengambilan sampel dilakukan di Kecamatan Denpasar Selatan dan pengujian Angka Kapang Khamir serta identifikasi Aspergillus sp.dilakukan di Laboratorium Bakteriologi Jurusan Analis Kesehatan Poltekkes Denpasar. Penelitian ini juga didukung dengan hasil observasi dan wawancara yang dilakukan pada saat pengambilan sampel. Sampel jamu kunyit yang digunakan merupakan seluruh jamu kunyit yang dijual oleh pedagang di Kecamatan Denpasar Selatan dengan jumlah sampel yang diambil adalah 23 sampel jamu kunyit, didapat dengan menggunakan teknik cluster sampling.

\section{HASIL DAN PEMBAHASAN}

\section{A. HASIL}

\section{Karakteristik objek penelitian}

Jamu kunyit yang digunakan pada penelitian ini yaitu seluruh jamu kunyit, baik yang dijual dengan cara dituang pada saat itu juga oleh pedagang jamu gendong maupun jamu kunyit yang sudah dikemas dalam botol yang dijual oleh pedagang yang menetap. Pada penelitian ini, jumlah sampel yang digunakan adalah 23 sampel jamu kunyit. Jamu kunyit yang digunakan sebagai objek penelitian memiliki warna khas kunyit yaitu kuning, memiliki rasa pahit dan memiliki aroma khas kunyit dan cair. Beberapa pedagang jamu kunyit juga menambahkan variasi rasa yaitu dengan menambahkan madu atau asam jawa untuk mengurangi rasa pahit dari kunyit.

\section{Uji Angka Kapang Khamir (AKK)}

Berdasarkan hasil pemeriksaan terhadap 23 sampel jamu kunyit, terdapat 8 sampel jamu kunyit yang mengandung fungi melebihi standar (35\%) dan terdapat 15 sampel jamu kunyit yang memenuhi standar (65\%) yang kemudiam dibandingkan dengan standar yang telah ditetapkan oleh BPOM RI Nomor 12 Tahun 2014 yang menyatakan bahwa obat tradisional tidak boleh mengandung fungi lebih dari $10^{3}$ koloni/mL.

\section{Identifikasi Aspergillus sp.}

Berdasarkan hasil pemeriksaan terhadap 23 sampel jamu kunyit, sebanyak 2 sampel positif Aspergillus sp. (9\%) dan 21 sampel negatif Aspergillus sp. $(91 \%)$. 
a. Identifikasi makroskopis

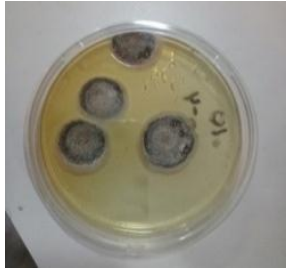

Hasil

Makroskopis

Koloni

Aspergillus sampel 10

b. Identifikasi mikroskopis

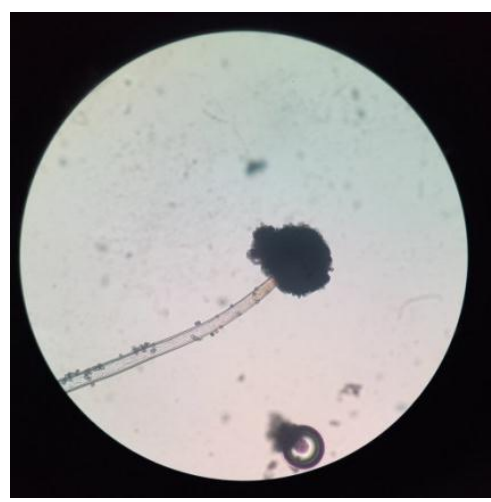

Hasil Pengamatan Mikroskopis Aspergillus sp.pada perbesaran 40x, jenis Aspergillus yang ditemukan pada kedua sampel adalah Aspergillus niger.

\section{Observasi dan Wawancara}

a. Kemasan jamu kunyit

Berdasarkan jenis kemasan jamu yang digunakan, terdapat 13 jamu dengan menggunakan kemasan botol tidak berlabel (56\%) dan 10 jamu dengan kemasan botol berlabel (44\%).

b. Pemakaian Kemasan

Berdasarkan lama pemakaian kemasan jamu kunyit, didapatkan bahwa terdapat 10 jamu kunyit yang memakai kemasan sekali pakai (56\%) dan 13 jamu kunyit yang menggunakan kemasan yang dipakai berulang-ulang (44\%).

c. Jenis Produksi Jamu Kunyit

Berdasarkan wawancara yang dilakukan kepada pedagang jamu kunyit mengenai jamu kunyit yang dijual di Denpasar Selatan, bahwa terdapat 13 jamu kunyit yang dibuat sendiri oleh pedagang jamu (56\%), dan terdapat 10 jamu kunyit yang dibuat oleh orang lain sebagai hasil industri rumah tangga $(44 \%)$.

d. Penyimpanan Jamu

Berdasarkan hasil wawancara terhadap pedagang jamu kunyit mengenai jamu kunyit yang dijual di Denpasar Selatan, bahwa terdapat 2 jamu kunyit yang apabila tidak laku terjual akan disimpan pada kulkas $(8,7 \%)$, dan terdapat 21 jamu kunyit yang disimpan pada suhu ruang jika tidak laku terjual $(91,3 \%)$

\section{B. PEMBAHASAN}

\section{Uji Angka Kapang Khamir}

Pemeriksaan Angka Kapang Khamir (AKK) merupakan salah satu uji yang dilakukan untuk melihat kualitas bahan pangan dari aspek mikrobiologi. Pada pengujian uji AKK dilakukan pada sampel jamu kunyit yang dijual di kawasan Denpasar Selatan. Pengujian 
AKK pada penelitian ini dimulai dengan melakukan inokulasi sampel jamu kunyit pada media SDA menggunakan metode sebar dan kemudian dihitung koloninya dengan menggunakan metode hitung cawan. Hasil pengujian yang disajikan pada Tabel 3 menunjukkan bahwa 35\% sampel jamu kunyit memiliki nilai AKK melebihi standar sehingga sampel jamu kunyit tersebut tidak layak untuk dikonsumsi. Sebanyak 65\% sampel jamu kunyit memiliki nilai AKK yang berada dalam rentang normal dan memenuhi standar. Pada penelitian ini standar yang digunakan adalah ketentuan yang ditetapkan oleh BPOM RI Nomor 12 Tahun 2014 bahwa cairan obat tradisional tidak boleh mengandung AKK lebih dari $10^{3}$ koloni $/ \mathrm{mL}$. Berdasarkan hasil penelitian yang telah dilakukan, dapat diketahui bahwa nilai AKK tertinggi adalah sebanyak 184,1 x $10^{3}$ koloni/mL dan nilai $\mathrm{AKK}$ terendah adalah $<10 \mathrm{koloni} / \mathrm{mL}$. Hasil penelitian sejalan dengan penelitian dari $66,7 \%$ jamu yang diuji menunjukkan nilai yang melebihi nilai standar yang ditetapkan oleh BPOM RI Nomor 12 Tahun 2014. Hasil pada sampel jamu kunyit yang diuji terdapat satu sampel yang menunjukkan nilai yang melebihi standar yaitu 4,6 x $10^{3}$ koloni $/ \mathrm{mL}$, sehingga jamu tersebut tidak layak untuk dikonsumsi ${ }^{5}$.
Berdasarkan hasil observasi yang dilakukan bahwa terdapat beberapa karakteristik jamu kunyit yang dapat mempengaruhi adanya pertumbuhan kapang dan khamir yaitu kemasan jamu kunyit, lama pemakaian kemasan, jenis produksi jamu kunyit dan penyimpanan jamu kunyit. Berdasarkan karakteristik kemasan jamu kunyit dan lama pemakaian kemasan, didapatkan hasil bahwa koloni yang paling banyak tumbuh adalah pada sampel kemasan jamu kunyit dengan label yaitu sebanyak 8 sampel jamu kunyit (35\%) dan kemasan jamu kunyit tanpa label memiliki nilai AKK yang masih dalam rentang normal dengan jumlah 15 sampel jamu kunyit (65\%). Tingginya niali AKK pada jamu kunyit kemasan berlabel disebabkan oleh penggunaan kemasan yang kurang bersih karena tidak melalui proses sterilisasi terlebih dahulu dan kondisi kemasan yang tidak kering sehingga menyebabkan pertumbuhan kapang dan khamir. Selain itu, berdasarkan hasil observasi diketahui bahwa jamu kunyit yang disimpan dalam kemasan berlabel biasanya akan disimpan kembali selama lebih dari 1 hari pada suhu ruang sehingga memberikan waktu bagi spora fungi untuk tumbuh pada jamu, sedangkan pada jamu kunyit dengan kemasan yang 
tidak berlabel akan habis terjual setiap harinya sehingga tidak melewati proses penyimpanan.

Berdasarkan hasil pengamatan yang telah dilakukan diketahui bahwa kapang dan khamir tumbuh optimal pada penyimpanan hari ke-3 sampai hari ke-5 pada suhu ruang. Hasil penelitian yang dilakukan pada sampel roti tawar dengan penyimpanan pada suhu kamar $25^{\circ} \mathrm{C}$, bahwa pada penyimpanan hari ke-4, jumlah kapang yaitu $8,4 \quad$ x $\quad 10^{4}$ koloni/gram, pada penyimpanan hari ke5 jumlah kapang yaitu $9,5 \times 10^{4}$ koloni/gram dan selanjutnya pada penyimpanan hari ke-6 jumlah kapang yaitu $13,3 \times 10^{4}$ koloni/gram. Jumlah kapang pada penyimpanan suhu kamar $25^{\circ} \mathrm{C}$ setiap harinya terjadi peningkatan ${ }^{7}$. Penelitian yang dilakukan pada sampel sirup temulawak yang disimpan selama 4 minggu pada suhu $35^{\circ} \mathrm{C}$, didapatkan hasil bahwa semakin lama penyimpanan maka jumlah mikroorganisme pada sampel sirup makin meningkat, dimana diketahui pada pada awal pemeriksaan didapatkan hasil 2,6 $\times 10^{1}$ koloni $/ \mathrm{mL}$ dan pada minggu keempat didapatkan hasil 7,6 $\mathrm{x}$ $10^{2}$ koloni $/ \mathrm{mL}^{8}$. Jenis produksi jamu kunyit di Denpasar Selatan terdiri dari dua jenis yaitu dibuat sendiri oleh penjual jamu dan dibuat oleh industri rumah tangga. Dari kedua jenis produksi jamu tersebut, didapatkan pertumbuhan koloni kapang dan khamir pada sampel jamu kunyit. Hal ini disebabkan oleh proses pembuatan jamu kunyit yang tidak sesuai dengan CPOTB, sehingga dapat menimbulkan pertumbuhan fungi pada jamu kunyit. menurut Pencucian yang bersih terhadap bahan baku jamu kunyit yaitu rimpang kunyit, dapat meminimalkan pertumbuhan kapang dan khamir pada jamu' ${ }^{9}$ Selain itu, pemanasan juga sangat berperan penting dalam pembuatan jamu, dimana pemanasan dilakukan untuk mematikan spora kapang dan khamir $^{10}$. Dari hasil penelitian yang dilakukan terhadap 23 sampel jamu kunyit yang dijual di wilayah Denpasar Selatan terdapat 35\% jamu kunyit yang tidak memenuhi standar karena memiliki nilai AKK yang melebihi standar, sehingga jamu tersebut tidak layak untuk dikonsumsi.

\section{Identifikasi Aspergillus sp.}

Identifikasi Aspergillus $s p$. digunakan untuk mengetahui ada tidaknya Aspergillus sp. pada sampel jamu kunyit. Aspergillus sp. dapat mengeluarkan aflatoksin yang dapat bersifat toksik bagi manusia apabila masuk kedalam tubuh. Berdasarkan hasil yang disajikan pada Tabel 4 diketahui bahwa terdapat 2 sampel jamu kunyit mengandung koloni kapang yaitu 
Aspergillus sp. dapat dikatakan bahwa sampel tersebut kualitasnya menurun karena adanya pertumbuhan Aspergillus sp. dengan jenis Aspergillus niger. Hasil penelitian serupa yang dilakukan pada empat sampel jamu ditemukan positif Aspergillus sp.dan jenis kapang yang paling banyak ditemukan dari keempat sampel jamu tersebut adalah Aspergillus niger dan Aspergillus flavus ${ }^{6}$. Pertumbuhan Aspergillus sp. pada jamu kunyit dapat disebabkan oleh adanya kontaminasi dari lingkungan yaitu udara. Pada saat pedagang jamu menuangkan jamu kunyit kedalam botol tidak mementingkan lokasi penuangan jamu. Hasil penelitian menyebutkan kontaminasi jamur Aspergillus sp. dapat melalui udara yang mengandung Aspergillus sp. Spora Aspergillus sp. berukuran kecil yaitu 3,0-4,5 $\mathrm{mm}$ dan dapat terbang dengan mudah bercampur dengan udara, sehingga apabila proses pembuatan jamu kunyit dan tempat penjualan yang tidak bersih, maka jamu kunyit yang dibuat akan terkontaminasi oleh Aspergillus $s p^{11}$. Selain itu, kontaminasi oleh spora Aspergillus sp. yang terjadi di luar ruangan dapat disebabkan oleh organisme yang membusuk dan adanya asap kendaraan bermotor $^{12}$.
Identifikasi Aspergillus sp., pada penelitian ini dilakukan dengan 2 metode, yaitu secara makroskopis dan mikroskopis. Dari 23 sampel jamu kunyit, terdapat 2 sampel jamu kunyit yang ditumbuhi koloni Aspergillus sp. yaitu sampel 10 dan sampel 22. Pada pengamatan makroskopis pada sampel 10 yang disajikan pada Gambar 6, didapatkan koloni Aspergillus sp. dengan ciri-ciri koloni tunggal, berwarna kuning kehitaman, bentuk koloni bulat, tekstur seperti beludru. Sedangkan pada sampel 22 yang disajikan pada Gambar 7 didapatkan koloni Aspergillus sp. dengan ciri-ciri koloni tunggal, berwarna hitam, bentuk koloni bulat, tekstur berserabut seperti beludru.

Pada pengamatan secara mikroskopis dengan menggunakan mikroskop pada perbesaran 40x, ditemukan bahwa pada kedua sampel jamu kunyit mengandung Aspergillus niger. Hal tersebut sesuai dengan ciri-ciri koloni Aspergillus sp. Pada pembuatan biakan murni Aspergillus niger pada media PDA, yaitu tampak koloni berbentuk bulat, tekstur lembut, tepi koloni rata, serta berwarna hitam dan coklat kehitaman. Koloni Aspergillus sp. yang didapatkan pada media SDA yang digunakan dalam penelitian ini tidak ada perbedaan dengan koloni Aspergillus sp. 
yang ditumbuhkan pada media PDA tersebut. Hal ini dikarenakan kedua media memang diperuntukkan untuk pertumbuhan jamur. Kedua media mengandung karbohidrat, pepton dan dektrose yang cukup tinggi sehingga mampu memenuhi kebutuhan nutrisi yang akan digunakan untuk pertumbuhan jamur $^{12}$. Pada pengamatan morfologi secara mikroskopis terlihat jamur Aspergillus niger mempunyai hifa hialin dan struktur hifa memanjang tidak bercabang, konidiofor bersekat, konidia bulat dan berwarna coklat kehitaman. Dari hasil penelitian yang dilakukan terhadap 23 sampel jamu kunyit yang dijual di Denpasar Selatan terdapat pertumbuhan Aspergillus sp. pada 2 sampel jamu kunyit sehingga kedua jamu tersebut tidak layak untuk dikonsumsi ${ }^{13}$.

\section{SIMPULAN}

Berdasarkan hasil penelitian dapat ditarik simpulan sebagai berikut:
1. Jumlah Angka Kapang Khamir yang ada pada jamu kunyit yang dijual di kawasan Denpasar Selatan ditemukan AKK tertinggi yaitu $184,1 \times 10^{3} \mathrm{koloni} / \mathrm{mL}$ dan nilai AKK terendah $<10$ koloni/mL

2. Nilai Angka Kapang Khamir pada jamu kunyit memenuhi syarat 8 sampel jamu kunyit, dan yang tidak memenuhi syarat 15 sampel jamu kunyit, berdasarkan standar kualitas BPOM RI Nomor 12 Tahun 2014 tentang obat tradisional.

3. Hasil identifikasi Aspergillus sp. yang ada pada jamu kunyit yang dijual di kawasan Denpasar Selatan ditemukan positif Aspergillus sp. sebanyak 2 sampel jamu kunyit (9\%) dan 21 sampel negatif Aspergillus sp.(91\%), serta jenis yang ditemukan adalah Aspergillus niger.

Kesehatan. 1st ed. Yogyakarta; 2015. 177-180 p.

3. Thearesti CC. Uji Angka

Kapang/Khamir (AKK) Identifikasi E.coli dalam jamu kunyit asam dari penjual jamu di wilayah Ngawen Klaten. 2015; Available from: https://repository.usd.ac.id/2724/2/1 28114072_full.pdf

2. Putra WS. Kitab Herbal Nusantara :

Aneka Resep dan Ramuan Obat untuk Berbagai Gangguan

Meditory | ISSN Online : 2549-1520, ISSN Cetak : 2338 - 1159, Vol. 7, No. 1, Juni 2019 
Kadek Dewi Amba Rahayu, dkk., Uji Angka Kapang Khamir dan Identifikasi Aspergillus Species Pada Jamu Kunyit di Denpasar Selatan

4. Kepala P, Pengawas B, Dan O, Indonesia R, Cara T, Sarana P, et al. Badan pengawas obat dan makanan republik indonesia. 2012;1-28.

5. Retno DN. Uji Cemaran Kapang, Khamir dan Bakteri Staphylococcus aureus pada Jamu Gendong di Pasar Gedhe Surakarta. 2016; Available from:

https://digilib.uns.ac.id/dokumen/de tail/55109/Uji-Cemaran-Kapang-

Khamir-dan-Bakteri-

Staphylococcus-aureus-pada-JamuGendong-di-Pasar-Gedhe-Surakarta

6. Sukmawati PA, Praborini MW, Kawuri R. Identifikasi Fungi Dan Total Bakteri Pada Jamu Tradisional Di Pasar Kedonganan Kelurahan Jimbaran Kabupaten Badung Provinsi Bali. J Biol Univ Udayana [Internet]. 2012;15(2):315. Available from:

https://ojs.unud.ac.id/index.php/BIO /article/view/12100

7. Babay L. Pengaruh Suhu Dan Lama PenyimpananTerhadap Jumlah Kapang Pada Roti Tawar. J Kesehat Masy. 2013;1-9.

8. Suwita IK, Kristianto Y, Purwaningsih FY. Pendugaan Umur Simpan Sirup Temulawak (Curcuma xanthorriza Roxb) Madu dan Ekstrak Ikan Gabus
(Ophiocepalus striatus) dengan Model Arrhenius dan Model Q10. J Ilm Fak Pertan Univ Yudharta Pasuruan. 2012;2(1):18-35.

9. Prasetyo, Inoriah E. Pengelolahan Budidaya Tanaman Obat-Obatan. 2013. p. 155.

10. Aminah NS, Supraptini.

Pengamatan Jenis-Jenis Jamur yang Ditemukan Pada Minuman Susu Segar dan Susu Kemasan. J Media Litbang Kesehat. 2005;XV.

11. Ariana D. IDENTIFIKASI SPESIES JAMUR PADA RUMAH MAKAN DI KAWASAN STASIUN GUBENG SURABAYA J Muhammadiyah Med Lab Technol. 2011;2(2).

12. Wulandari DE, Asrul, Lakani I. Phytophthora palmivora Selection of Aspergillus niger FungalAntagonist from Several Cacao Plantations to Controlling Phytophthora palmivora. J Agrol. 2016;23(3):233-42.

13. Taurisia PP, Proborini MW, Nuhantoro I. Pengaruh Media Terhadap Pertumbuhan dan Biomassa Cendawan Alternaria alternata (Fries) Keissler. J Biol. 2000;19(1):30-3. 